\title{
CƠ CHÊ CỦA DÒNG CHẢY SÓNG TRONG ĐỚI SÓNG TRÀN KHU VỰC BÃI BIỂN NHA TRANG
}

\author{
Nguyễn Kim Cương ${ }^{1,2 *}$, Trần Văn $M \tilde{y}^{2}$, Lefebvre Jean-Pierre ${ }^{2,3}$ \\ ${ }^{1}$ Khoa Khi tương Thủy văn và Hải dương học, Trường ĐH Khoa hoc Tụ nhiên, ĐH QGHN \\ ${ }^{2}$ Trung tâm Động lưc học Thủy khi Môi truờng, Truờng ĐH Khoa học Tụ nhiên, ĐH QGHN \\ ${ }^{3}$ UMR 5566-LEGOS (IRD-CNRS-CNES-Paul Sabatier University, Toulouse, France) \\ "E-mail: cuongnk@hus.edu.vn
}

Ngày nhận bài: 28-12-2015

\begin{abstract}
TÓM TĂT: Bài báo này trình bày các kết quả phân tích số liệu số liệu dòng chảy và năng luợng rối đo đạc và mô phỏng trong đọt khảo sát thực địa tại Nha Trang vào tháng 5 năm 2013. Các số liệu dòng chảy và năng lương rối được đo đạc trong đới sóng tràn bằng máy Vectrino ADV. Để hiểu được bản chất của sự lan truyền sóng trong đới sóng tràn trên bãi biển Nha Trang, một mô hình số dựa trên lý thuyết võ đập cũng đã được triển khai. Các kết quả tính toán đã cho thấy mô hình có thể mô phỏng tuơng đối tốt quá trình lan truyền trên bãi của bore nước. Độ cao của bore nuớc đã được chứng minh tỷ lệ tuyến tính với độ cao sóng ngoài khơi. Phân bố của năng lương rối cũng đã được định lương và phân tích.
\end{abstract}

Tù khóa: Sóng tràn, bãi biển Nha Trang, Vectrino ADV, năng luợng rối.

\section{GIÓII THIẸU CHUNG}

Đới sóng tràn (swash zone) là một bộ phận của biển mà khoảng rộng từ giới hạn sóng bắt đầu vỡ cho đến giới hạn cao nhất mà nước biển có thể đi lên. Đây là một khu vực rất biến động và phức tạp, nơi xảy ra các quá trình thủy động lực học và hình thái học khác nhau.

Đới sóng tràn là nơi tiếp giáp trực tiếp giữa đất liền và biển. Đây là dải hẹp và đầy biến động cũng như rất phức tạp của các quá trình thủy động lực học. Tuy nhiên, sự thay đổi đường bờ, bãi biển chính là kết quả của các quá trình rối, quá trình vận chuyển trầm tích ... cũng như các tác động trực tiếp của sóng. Ranh giới và chức năng của đới sóng tràn khác nhau về thời gian tùy theo điều kiện thủy triều và sóng. Chính sự thay đổi này định hình nên địa mạo của các bãi biển. Nghiên cứu này tập trung nghiên cứu bản chất quá trình lan truyền của sóng sau khi sóng đổ.
Cơ chế sóng tràn bị chi phối bởi các đặc điểm của khu vực nghiên cứu (độ dốc bãi biển, phân bố kích thước hạt, chế độ sóng) [1]. Bởi vì đới sóng tràn không ổn định, năng lượng rối lớn, thủy triều chi phối, dòng chảy hẹp, rất khó khăn để có được các dữ liệu chính xác trong đới sóng tràn (hình 1). Các nghiên cứu trước đã tiến hành bằng cách sử dụng thiết bị đo dòng chảy tần số cao $(\mathrm{ADV})$ và cảm biến quang tán xạ ngược [2-6]. Gần đây, các kỹ thuật mới (ADV, Video) đã được thử nghiệm thành công $[7,8]$ nhưng hầu hết các nghiên cứu đều thực hiện trong phòng thí nghiệm. Trong nghiên cứu này, quá trình đo đạc và kết quả đo đạc sóng tràn trên bãi biển Nha Trang đã được trình bày. Từ đó bản chất vật lý của quá trình lan truyền sóng sau khi sóng đổ có thể được phân tích làm sáng tỏ. Bên cạnh đó, Puleo và Holland, 2001; Puleo và nnk., 2002; Broccini và Baldock, 2008; Hugues và Baldock, 2004 [9-11] cũng đã mô phỏng quá trình lan truyền sóng trong đới 
sóng tràn bằng mô hình mô phỏng cơ chế vỡ đập (dambreak model) và đã khẳng định khả năng ứng dụng của dạng mô hình này khi mô phỏng trường dòng chảy trên bãi biển. Nghiên cứu này cũng áp dụng một mô hình tương tự để xem xét khả năng mô phỏng của dạng mô hình này cho bãi biển thực tế như bãi biển Nha Trang.

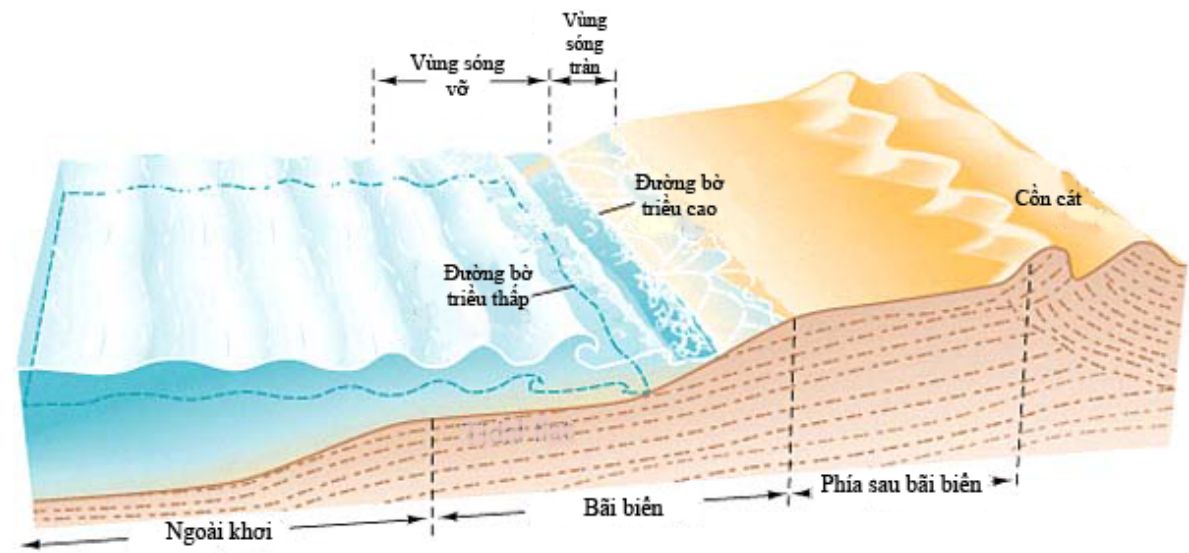

Hình 1. Sơ đồ mặt cắt bãi biển và phân bố sóng

\section{PHƯƠNG PHÁP NGHIÊN CÚU}

\section{Khảo sát thực địa}

Số liệu khảo sát trong bài báo này được tiến hành đo dòng chảy trong đới sóng tràn bằng máy Vectrino II trong tháng 5 năm 2013 tại bãi biển Nha Trang. Vì đới sóng tràn thay đồi theo dao động của độ cao mực nước thủy triều nên khi các tác giả tiến hành đo dòng chảy trong đới sóng tràn bằng máy Vectrino II cũng phải dịch chuyển vị trí đặt máy theo dao động của độ của mực nước thủy triều. Do đó phải chọn vị trí đặt máy Vectrino II trong đới sóng vỡ và sóng tràn sao cho đầu sensor ngập trong nước nhiều nhất. Khoảng cách từ đầu sensor tới đáy được xác định khoảng $7,5 \mathrm{~cm}$. Do Vectrino II có khoảng trắng không đo được cách đầu đo khoảng $4 \mathrm{~cm}$ nên trong nghiên cứu này đã đo được trong khoảng $3,5 \mathrm{~cm}$ với 35 cell, khoảng cách mỗi cell là $1 \mathrm{~mm}$, tần số đo là $0,015 \mathrm{~s}$ (hình 2). Các số liệu đo đạc của máy Vectrino được hỗ trợ bởi một trạm đo sóng ngoài khơi bằng máy AWAC tại độ sâu $10 \mathrm{~m}$.

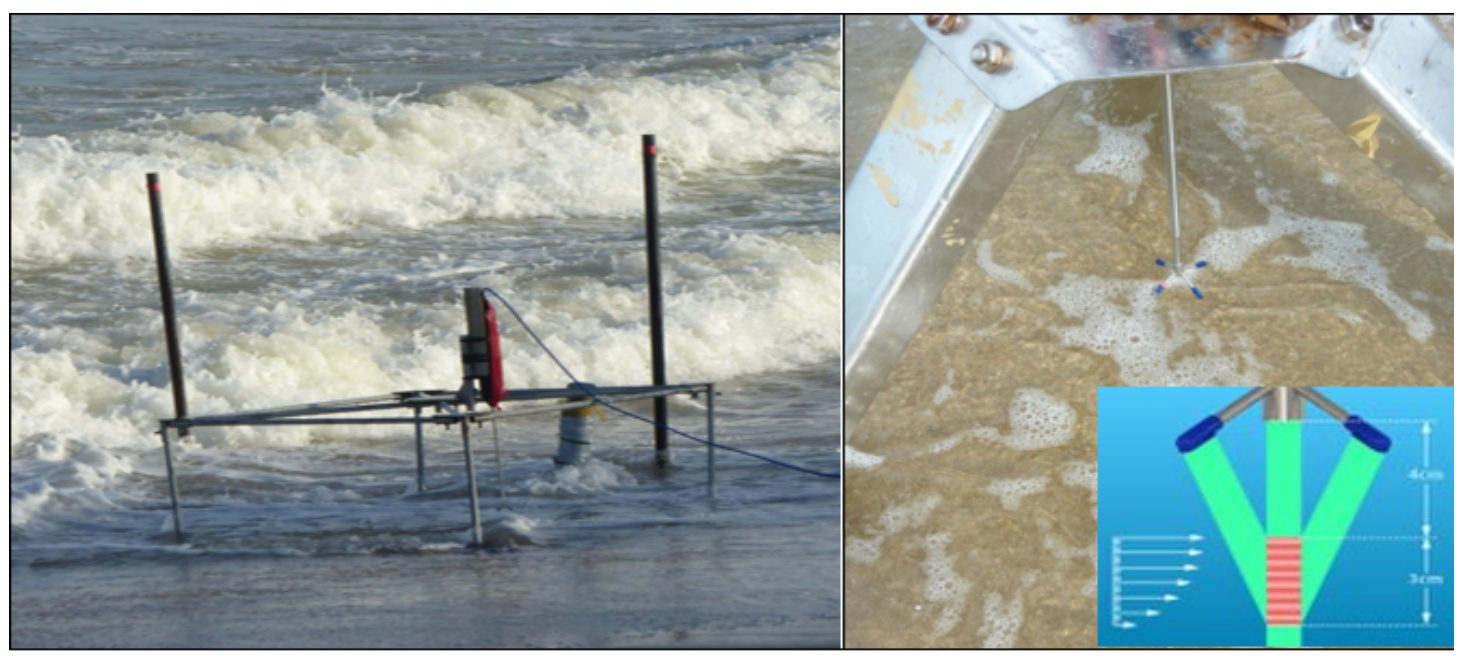

Hình 2. Triển khai đo dòng chảy trong đới sóng tràn bằng Vectrino II (Nortek) 


\section{Mô hình số võ đập (dambreak model)}

Mô hình vỡ đập được phát triển trong nghiên cứu này đã ứng dụng phương trình nước nông hay còn gọi là phương trình Saint Venant. Phương trình tồng quát có dạng:

$$
\begin{gathered}
\frac{\partial U}{\partial t}+\frac{\partial F}{\partial x}=S \rightarrow U=\left[\begin{array}{l}
\eta \\
q
\end{array}\right] \\
F=\left[\begin{array}{c}
q \\
u q+\frac{1}{2} g\left(\eta^{2}-2 \pi z_{b}\right)
\end{array}\right] \\
S=\left[\begin{array}{c}
0 \\
-g \eta \frac{\partial z_{b}}{\partial x}
\end{array}\right]
\end{gathered}
$$

Trong đó: $\mathrm{t}$ : thời gian $(\mathrm{s}), \mathrm{U}$ : vector chứa các dòng chảy được bảo toàn $(\mathrm{m} / \mathrm{s})$, x: tọa độ Decartes $(\mathrm{m}), \mathrm{F}$ : thông lượng trong $\mathrm{x}$-hướng $\left(\mathrm{m}^{3} / \mathrm{s}\right), \mathrm{S}$ : nguồn $\left(\mathrm{m}^{3} / \mathrm{s}\right), \eta$ và $\mathrm{z}_{\mathrm{b}}$ là mức độ bề mặt nước, độ cao đáy so với mốc đo đạc bởi hệ thống cọc $(\mathrm{m}), \mathrm{h}=\eta-\mathrm{z}_{\mathrm{b}}, \mathrm{q}=$ uh: lưu lượng đơn vị chiều rộng $\left(\mathrm{m}^{3}\right), \mathrm{g}$ : gia tốc trọng trường $\left(\mathrm{m} / \mathrm{s}^{2}\right)$, u: vận tốc trung bình theo độ sâu $(\mathrm{m} / \mathrm{s})$, $\partial z_{b} / \partial x$ : độ dốc đáy.

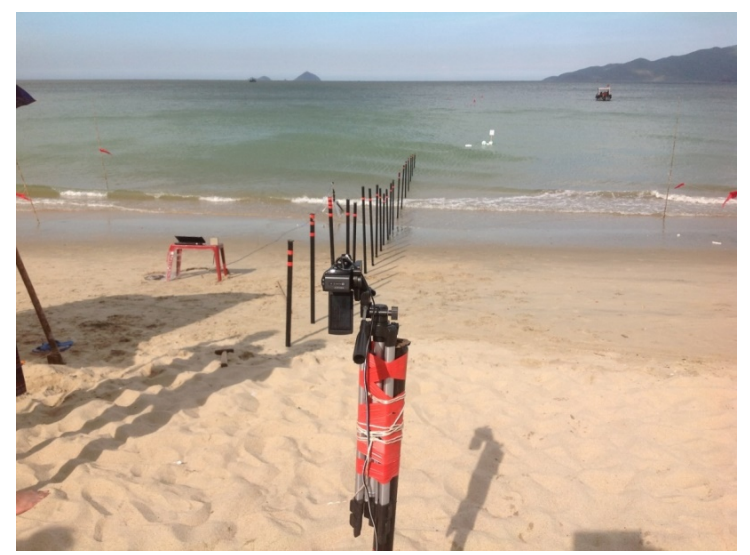

Hình 3. Quan trắc các yếu tố của sóng trong đới sóng tràn

Mô hình này được giải bằng phương pháp thể tích hữu hạn với ngôn ngữ lập trình Matlab. Để giải được mô hình số này, các điều kiện ban đầu cần được cung cấp: Độ cao của cột nước (bore) khi sóng đổ truyên lên bãi và độ dốc đáy. Độ dốc đáy được xác định bằng việc đo đạc cao độ bởi hệ thống 21 cọc (hình 3). Thông qua các hình ảnh thu được từ camera đặt ngang bãi (hình 3 ), độ cao của các bore nước có thể xác định và làm điều kiện ban đầu cho mô hình số. Với việc sử dụng camera độ phân giải cao như vậy hoàn toàn có thể xác định được khoảng cách từ máy Vectrino để phục vụ đo đạc và kiểm chứng kết quả của mô hình. Một trong những tham số khác đó là vận tốc ban đầu của bore nước được xác định bằng công thức: $u_{0}=2 \sqrt{g H_{b}}[11]$; trong đó $\mathrm{g}$ là gia tốc trọng trường; $H_{b}$ là độ cao cột nước ban đầu được xác định từ camera.

\section{KẾT QUẢ NGHIÊN CỨU}

\section{Quan hệ giữa độ cao sóng ngoài khơi và độ cao bore nước trong đới sóng tràn}

Như đã mô tả trên hình 3 , độ cao của bore nước có thể thu được thông qua xử lý ảnh do camera đặt trên bãi biển thu được. Hình 4 thể hiện mối quan hệ giữa độ cao bore nước và độ cao sóng ngoài khơi đo đạc bằng máy AWAC. Về cơ bản, sóng ngoài khơi khi lan truyền vào bờ và do ảnh hưởng của địa hình bãi biển nông nên biến dạng và đổ tạo nên các bore nước lan truyền lên trên bãi biển. Mặc dù quá trình này tương đối phức tạp và bị ảnh hưởng của nhiều yếu tố: hướng sóng, hướng gió, địa hình ... nhưng độ cao sóng ngoài khơi và độ cao của bore nước có mối quan hệ tương đối khăng khít (hình 4). Có thể kết luận rằng, độ cao của bore nước tỷ lệ thuận với độ cao sóng ngoài khơi.

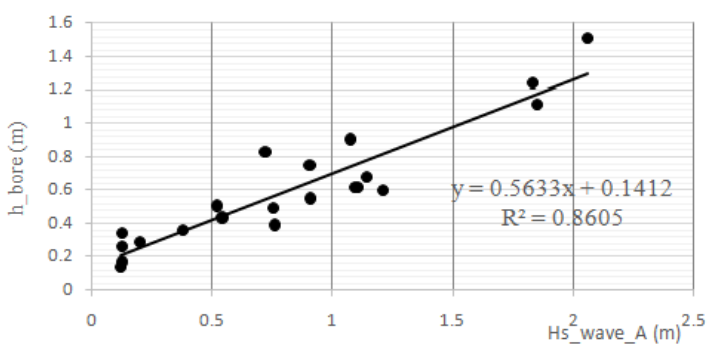

Hình 4. Mối quan hệ giữa độ cao sóng ngoài khơi và độ cao bore nước

\section{Phân bố vận tốc dòng chảy trong đới sóng tràn}

Sau khi sóng đổ, năng lượng sóng bị tiêu hao một phần và phần còn lại tiêp tục làm cho cột nước tiếp tục di chuyển lên trên bãi. Chính 
phần năng lượng này góp phần khuấy và đưa các hạt bùn, cát ra khỏi vị trí và dòng chảy do sóng sẽ mang ra khỏi vị trí ban đầu. Đây chính là cơ chế xói lở/bồi tụ làm thay đổi địa mạo bãi biển. Theo đó, xác định vận tốc và hướng của dòng chảy trong đới sóng tràn là việc quan trọng, góp phần xác định ảnh hưởng của sóng tới hình thái bờ biển.

Theo pha nước lên sau khi sóng đổ, các hạt nước hướng theo chiều chuyển động của tia sóng (về phía bờ) theo quán tính và chậm dần. Sau đó, theo pha nước rút xuống, các hạt nước chuyển động theo hướng ngược lại (hình 5).
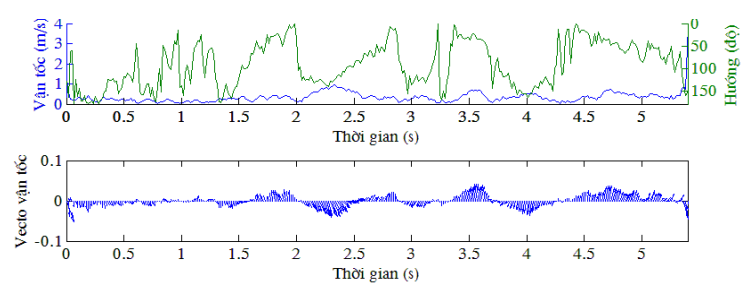

Hình 5. Biến thiên vận tốc và hướng dòng chảy trong đới sóng tràn lúc 8 h 48' ngày 29/5/2013

Trên hình 5 , dòng chảy trong đới sóng tràn diễn ra rất nhanh chỉ khoảng vài giây và hướng dòng chảy thay liên tục trong thời gian ngắn. Trong khoảng $5,39 \mathrm{~s}$, trong đới sóng tràn có tới 5 đợt nước lên và rút. Vận tốc dòng chảy trong đới sóng tràn lớn nhất là $1,2 \mathrm{~m} / \mathrm{s}$ trong khi hướng của dòng chảy thì không đối lập hoàn toàn. Điều này xảy ra do bãi biển là 2 chiều và sóng lan truyền không hoàn toàn vuông vóc với bãi biển dưới ảnh hưởng của địa hình bãi biển. Các kết quả tương tự có thể thu được vào các thời điểm khác trên bãi biển Nha Trang (hình 6).

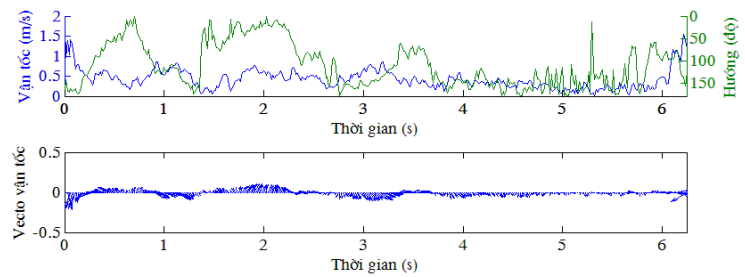

Hình 6. Biến thiên vận tốc và hướng dòng chảy trong đới sóng tràn lúc 8 h 49’ ngày 29/5/2013

Một trong những kết quả đáng chú ý từ số liệu đo đạc đó là khẳng định về các pha nước lên xuống sau khi sóng đồ là không đồng nhất với sự liên tiếp hoặc ngược hướng trên bãi biển thực tế. Trên hình 7 dẫn ra một chuỗi phân bố dòng chảy trong đới sóng tràn theo thời gian. Trong $3 \mathrm{~s}$ đầu, có 2 pha nước đi xuống và 1 pha lên trong khoảng $1 \mathrm{~s}$ sau đó. Do bãi biển phân bố hai chiều nên sau khi sóng đổ, tùy theo địa hình bore nước có thể đi vuông góc với bãi biển hoặc đi xiên. Khi pha lên và pha xuống của bore nước tương tác với nhau có thể dẫn đến sự phân bố bất đối xứng của dòng chảy giữa pha nước lên và pha nước xuống. Điều này cũng tương tự trong pha nước lên (hình 8).

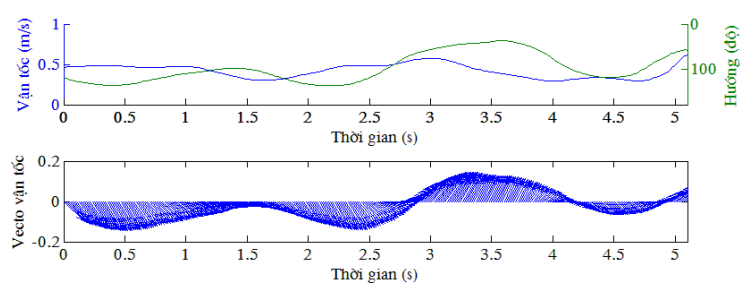

Hình 7. Biến thiên vận tốc và hướng dòng chảy trong đới sóng tràn lúc 16 h 35' ngày 29/5/2013

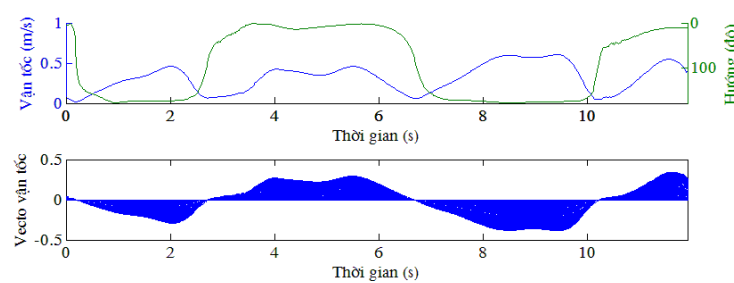

Hình 8. Biến thiên vận tốc và hướng dòng chảy trong đới sóng tràn lúc 9 h 04' ngày 30/5/2013

\section{Phân bố năng lượng rối trong đới sóng tràn}

Khi sóng biển lan truyền từ ngoài khơi vào bờ, độ cao sóng tăng và khi lan truyền tới một giá trị tới hạn so với độ sâu nước, sóng sẽ đổ và tạo thành các bore nước lan truyền lên bãi. Năng lượng do sóng đổ sẽ biến chuyển động sóng thành chuyển động rối, đặc trưng bởi các xoáy cuộn có kích thước khác nhau. Chính quá trình này góp phần làm khuấy các hạt trầm tích khỏi vị trí và đưa vào trạng thái lơ lửng. Do vậy, dòng chảy có thể mang đi và làm thay đổi địa mạo trên bãi cũng đường bờ.

Hình 9 thể hiện phân bố năng lượng rối trong đới sóng vỡ và sóng tràn tương ứng với các pha của bore nước. Năng lượng rối đạt giá trị lớn nhất là khoảng $97 \mathrm{~m}^{2} / \mathrm{s}^{2}$ và nhỏ nhất là 
$72 \mathrm{~m}^{2} / \mathrm{s}^{2}$. Khi vận tốc dòng chảy trong đới sóng tràn tăng thì năng lượng rối trung bình cũng tăng dần lên, năng lượng rối trong pha nước lên thường lớn hơn so với trong pha nước đi xuống. Mặc dù vậy, năng lượng rối trung bình không lớn nhất khi vận tốc dòng chảy đạt giá trị lớn nhất.
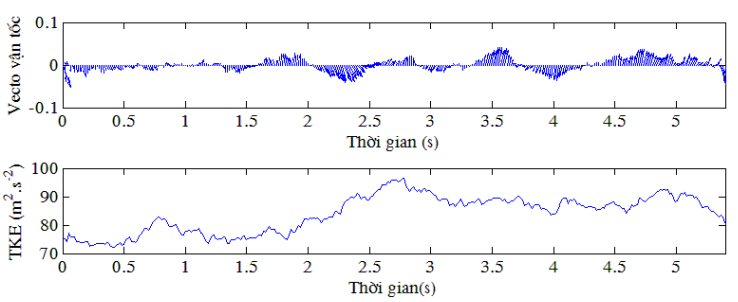

Hình 9. Biến thiên vận tốc và hướng dòng chảy và năng lượng rối trung bình trong đới sóng tràn lúc 8 h 48' ngày 29/5/2013

Khi sử dụng máy Vectrino với độ phân giải cao và tần số cao, năng lượng rối trong bore nước có thể được phân tích và làm sáng tỏ cơ chế của quá trình chuyển động rối. Trong khoảng $35 \mathrm{~mm}$ (từ $40 \mathrm{~cm}$ đến $75 \mathrm{~cm}$ từ đầu sensor), năng lượng rối có sự thay đổi rất lớn theo độ sâu. Một điểm đáng chú ý là trong một lớp nước mỏng $3,5 \mathrm{~cm}$ sát đáy, năng lượng rối có phân bố rất khác biệt trong các tầng (hình 10). Năng lượng rối cao hơn ở phía dưới đáy biển và đạt giá trị trong khoảng từ $50 \div$ $400 \mathrm{~m}^{2} / \mathrm{s}^{2}$. Những vị trí tập trung năng lượng rối cao gần như duy trì trong cả pha nước lên và xuống. Đây chính là nơi trầm tích bị khuấy động mạnh nhất.

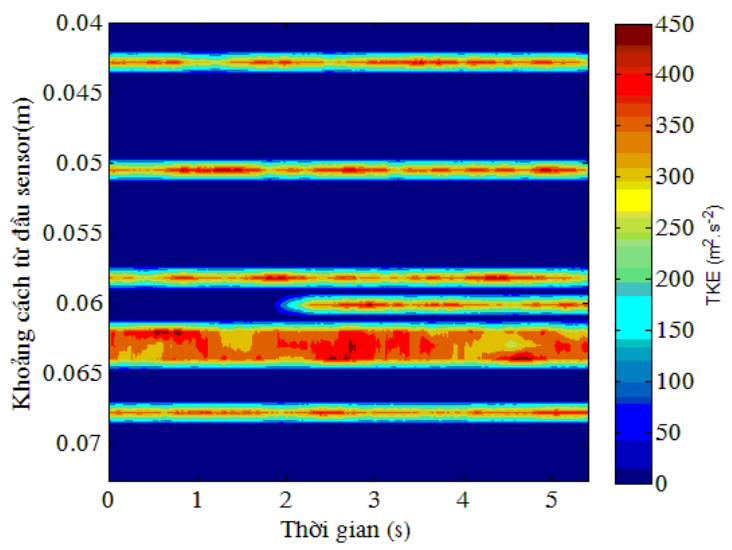

Hình 10. Phân bố năng lượng rối trong đới sóng tràn lúc 8 h 48 ' ngày 29/5/2013

\section{Mô phỏng vận tốc chuyển động bore nước bằng mô hình số Dam-break}

Trong bài báo này, mô hình số vỡ đập như đã mô tả ở trên đã được ứng dụng tính toán cho bãi biển Nha Trang. Tuy nhiên, mô hình mới chỉ dừng lại ở mức mô phỏng 1 chiều cho quá trình lan truyền sóng trên bãi biển thực. Độ dốc bãi biển cũng như độ cao ban đầu của bore nước được đưa vào từ các số liệu khảo sát tháng 5 năm 2013. Mô hình đã mô phỏng cho 4 trường hợp lan truyền nước với các độ cao và vận tốc ban đầu khác nhau (bảng 1). Vận tốc ban đầu của bore nước được xác định bằng công thức: $u_{0}=2 \sqrt{g H_{b}}[11]$.

Bảng 1. Các trường hợp mô phỏng

\begin{tabular}{cccc}
\hline Trưò̀ng hợp & $\begin{array}{c}\text { Độ cao bore } \\
\text { nước } \mathbf{~}\left(\mathbf{h}_{\mathbf{o}}-\mathbf{m}\right)\end{array}$ & $\begin{array}{c}\text { Vận tốc ban đầu } \\
\left(\mathbf{V}_{\mathbf{o}}-\mathbf{m} / \mathbf{s}\right)\end{array}$ \\
Trường hợp 1 & 0,14 & 1,172 \\
Trường hợp 2 & 0,509 & 2,35 \\
Trường hợp 3 & 0,909 & 2,986 \\
Trường hợp 4 & 1,509 & 3,85 \\
\hline
\end{tabular}

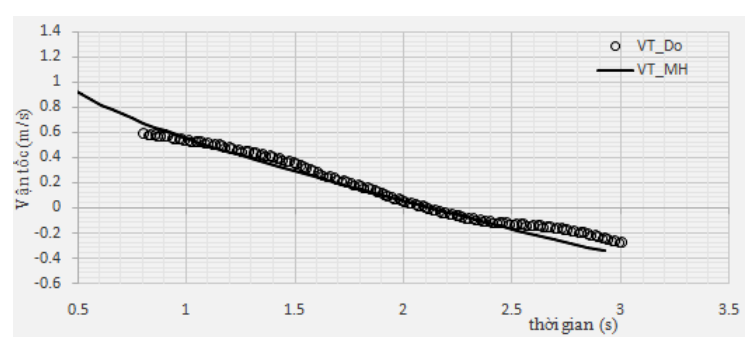

Hình 11. Biến thiên vận tốc dòng chảy trên bãi biển Nha Trang trong trường hợp 1 tại khoảng cách từ bore tới điểm đo $0,72 \mathrm{~m}$

Hình 11-14 thể hiện biến thiên theo thời gian của vận tốc bore nước tại các vị trí khác nhau trên bãi biển. Theo như vị trí xác định được từ camera đặt trên bãi, điểm tính toán trong mô hình được trích xuất tương ứng. Các giá trị thực đo được thể hiện bằng điểm hình tròn trong khi giá trị mô phỏng được thể hiện bằng đường liền nét. Có thể nhận thấy được, mô hình mô phỏng tương đối tốt vận tốc của dòng nước trong đới sóng tràn đặc biệt trong pha nước đi lên. Tuy vậy, trong pha nước xuống, giá trị vận tốc mô phỏng thường lớn hơn so với giá trị thực đo. Điều này là do trong mô hình số, các quá trình tương tác phức tạp 
giữa dòng nước đi xuống do trọng lực và bore nước đi lên chưa được tính đến. Khi dòng nước đi xuống gặp bore nước đi lên dẫn đến vận tốc dòng nước chuyển động chậm dần. Mặc dù vậy, có thể khẳng định mô hình số đã mô phỏng tương đối tốt vận tốc dòng nước ở các vị trí khách nhau trong các điều kiện sóng trên bãi biển.

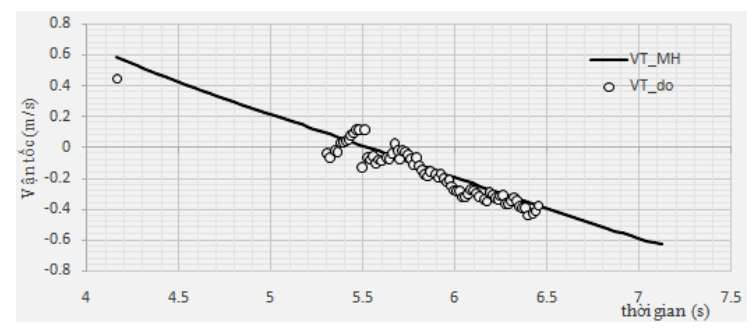

Hình 12. Biến thiên vận tốc dòng chảy trên bãi biển Nha Trang trong trường hợp 2 tại khoảng cách từ bore tới điểm đo $1,65 \mathrm{~m}$

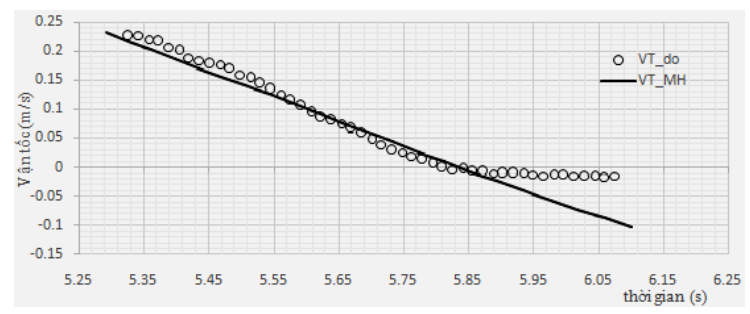

Hình 13. Biến thiên vận tốc dòng chảy trên bãi biển Nha Trang trong trường hợp 3 tại khoảng cách từ bore tới điểm đo $2,27 \mathrm{~m}$

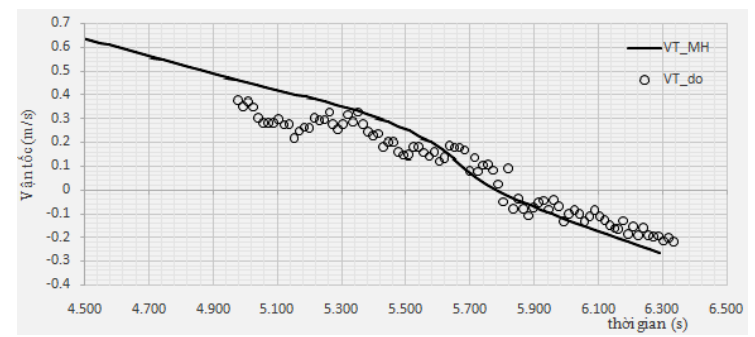

Hình 14. Biến thiên vận tốc dòng chảy trên bãi biển Nha Trang trong trường hợp 4 tại khoảng cách từ bore tới điểm đo $3,72 \mathrm{~m}$

\section{KẾT LUẬN}

Bài báo này trình bày các kết quả đo đạc và mô phỏng trường dòng chảy, năng lượng rối trong đới sóng tràn tại bãi biến Nha Trang. Các hệ thống đo đạc dòng chảy với độ phân giải và tần số cao đã được triển khai và cho ra các kết quả rất đáng chú ý. Mô hình toán cũng đã được ứng dụng để mô phỏng quá trình lan truyền bore nước trên bãi biển Nha Trang. Khi sóng lan truyền từ ngoài khơi vào bờ và bị tiêu tán năng lượng qua quá trình sóng đổ, độ cao của bore nước tạo thành sau khi sóng đổ tỉ lệ thuận với độ cao sóng ngoài khơi. Trên bãi biển thực tế, các sự kiện lên hoặc xuống của các bore nước có thể đan xen hoặc bất đối xứng với nhau. Khi có sự giao lưu giữa pha nước lên và xuống, năng lượng rối thường đạt cực đại. Đây chính là nguyên nhân ảnh hưởng đến quá trình bứt lên khỏi đáy của cát biển và làm thay đổi địa mạo bãi biển. Kết quả mô phỏng dòng chảy bởi mô hình số đã được so sánh với các kêt quả đo đạc và khẳng định rằng mô hình vỡ đập có thể mô phỏng cho dòng chảy trong đới sóng tràn ở các bãi biển thực tương đối đồng nhất.

Lò̀i cảm ơn: Nghiên cứu này được tài trợ bởi Trường Đại học Khoa học Tự nhiên trong đề tài mã số TN.15.22. Các số liệu đo đạc trong bài báo được cung cấp bởi đề tài Nghị định thư Việt Nam - Pháp: "Nghiên cứu các đặc trưng động học hình thái vùng vịnh và đề xuất ứng dụng các giải pháp tái tạo, nâng cấp bãi biển Nha Trang, tỉnh Khánh Hòa có tính đến ảnh hưởng của biến đổi khí hậu". Các tác giả xin cảm ơn những sự tài trợ và giúp đỡ này.

\section{TÀI LIỆU THAM KHẢO}

1. Masselink, G., and Puleo, J. A., 2006. Swash-zone morphodynamics. Continental Shelf Research, 26(5): 661-680.

2. Hughes, M. G., Masselink, G., and Brander, $R$. W., 1997. Flow velocity and sediment transport in the swash zone of a steep beach. Marine Geology, 138(1): 91-103.

3. Hughes, M. G., and Turner, I., 1999. The beachface. Handbook of Beach and Shoreface Morphodynamics. Wiley, Chichester, 119-144.

4. Puleo, J. A., Beach, R. A., Holman, R. A., and Allen, J. S., 2000. Swash zone sediment suspension and transport and the importance of bore-generated turbulence. Journal of Geophysical Research: Oceans, 105(C7): 17021-17044.

5. Baldock, T. E., 2004. Dynamics of a transient wave group breaking on a beach. Dynamics, 13, 17. 
Cơ chế của dòng chảy sóng trong đới sóng ...

6. Masselink, G., and Russell, P., 2005. Field measurements of flow velocities on a dissipative and reflective beachimplications for swash sediment transport. In Proceedings Coastal Dynamics (Vol. 5).

7. Vousdoukas, M. I., Kirupakaramoorthy, T., Oumeraci, H., De La Torre, M., Wübbold, F., Wagner, B., and Schimmels, S., 2014. The role of combined laser scanning and video techniques in monitoring wave-bywave swash zone processes. Coastal Engineering, 83, 150-165.

8. Lefebvre, J. P., Almar, R., Viet, N. T., Thuan, D. H., Binh, L. T., Ibaceta, R., and Duc, N. $V$., 2014. Contribution of swash processes generated by low energy wind waves in the recovery of a beach impacted by extreme events: Nha Trang, Vietnam. Journal of Coastal Research, 70(sp1): 663-668.
9. Puleo, J. A., and Holland, K. T., 2001. Estimating swash zone friction coefficients on a sandy beach. Coastal engineering, 43(1): 25-40.

10. Brocchini, M., and Baldock, T. E., 2008. Recent advances in modeling swash zone dynamics: Influence of surf-swash interaction on nearshore hydrodynamics and morphodynamics. Reviews of Geophysics, 46(3): 1-21.

11. Hughes, M. G., and Baldock, T. E., 2004. Eulerian flow velocities in the swash zone: Field data and model predictions. Journal of Geophysical Research, 109(C08009): 1-11.

12. Puleo J. A., Holland K. T., Slinn D. N., Smith, E., and Webb B. M., 2002. Numerical modelling of swash zone hydrodynamics. Proceedings of the $28^{\text {th }}$ International Conference on Coastal Engineering, ASCE, pp. 968-979.

\title{
MECHANISM OF WAVE - INDUCED FLOWS IN SWASH ZONE IN THE NHA TRANG BEACH, VIETNAM
}

\author{
Nguyen Kim Cuong ${ }^{1,2}$, Tran Van $\mathbf{M y}^{2}$, Lefebvre Jean-Pierre ${ }^{2,3}$ \\ ${ }^{1}$ Faculty of Hydro-Meteorology and Oceanography, Hanoi University of Science-VNU \\ ${ }^{2}$ Centre for Environmental Fluid Dynanics, Hanoi University of Science-VNU \\ ${ }^{3}$ UMR 5566-LEGOS (IRD-CNRS-CNES-Paul Sabatier University, Toulouse, France)
}

\begin{abstract}
This paper analyzed the measured and simulated data in the field survey in the Nha Trang beach in May 2013. The measurements in the surf and swash zones have been conducted. In order to address the quantification of the very shallow, highly turbulent flow in the swash zone, a high frequency micro profiler was deployed (Vectrino II, Nortek). In addition, a dambreak model to simulate process of wave propagation in the swash zone was developed and applied. It is confirmed that the numerical model reasonably reproduces the measured data. The height of water bore in the swash zone gets greater with the increase of offshore wave height. The results enable the estimation of the Reynolds stress component and Turbulent Kinetic Energy. Swash bed shear stresses play an important role in controlling the swash morphodynamic processes on sand and gravel beaches.
\end{abstract}

Keywords: Swash zone, Nha Trang beach, Vectrino ADV, TKE. 